\title{
Sterowanie spawarek MIG/MAG
}

\section{MIG/MAG welding machines control}

\section{Streszczenie}

Artykuły dotyczące teorii budowy urządzeń spawalniczych wyposażonych w zaawansowane systemy sterowania nierzadko publikowane są w Przeglądzie Spawalnictwa. Niniejszy artykuł przedstawia stosowane w nowoczesnych urządzeniach sposoby sterowania napięciem i prądem łuku spawalniczego wraz ze zwięzłą charakterystyką podstawowych różnic w sterowaniu.

\section{Abstract}

Articles regarding the theory of design of welding machines with high-tech control systems are often published in Welding Technology Review. Used in modern welding machines voltage and current control systems with brief characteristic of fundamental differences in regulation are presented in this article.

\section{Wstęp}

W spawaniu zwarciowym MIG/MAG o jakości połączenia decydują zjawiska fizyczne zachodzące nie w czasie zwarcia kropli, lecz w czasie jarzenia się łuku elektrycznego. $Z$ tego powodu fizycy zajmują się filmowaniem przechodzenia kropli w łuku, pomiarem rozkładu temperatury łuku spawalniczego, ciśnienia łuku, stopnia jonizacji, ilości oparów itd. [1, 2]. Z kolei dla technologa istotna jest stabilność procesu i jakość połączenia, a dla energoelektronika i konstruktora urządzeń istotne jest zrozumienie i hierarchiczne poukładanie tych spraw.

\section{Mechaniczne oderwanie kropli}

Przebiegi prądu i napięcia wraz ze zdjęciami łuku elektrycznego, uzyskane przy zastosowaniu tradycyjnego prostownika, przedstawiono na rysunku 1a [3]. Najważniejszą wadą procesu jest narastający podczas zwarcia, od punktu E do punktu F, prąd spawania, gdyż po oderwaniu kropli i ponownym zajarzeniu łuku, ze względu na dużą indukcyjność obwodu (dławiki), nie może od razu spaść do wartości przed zwarciem. Podczas zwarcia, ze względu na niskie napięcie, moc grzania jest niewielka. Jak udowodnił prof. Oshima z Instytutu Elektroniki Saitama University, po rozwarciu i zajarzeniu łuku w wyniku wzrostu napięcia

Mgr inż. Ryszard Jastrzębski - Instytut Łączenia Metali, Kraków. moc gwałtownie wzrasta, powodując nadmierne nagrzanie jeziorka spawalniczego - drut topi się zbyt szybko, powodując rozprysk [4]. Wyrzucana kropla powoduje wyrzucenie jonów, co objawia się krótkotrwałym spadkiem prądu do zera. Ruchy konwekcyjne w bardzo krótkim czasie zatykają „dziurę jonową”, przywracając przepływ prądu i zajarzenie łuku, a w konsekwencji prowadzą do stabilnego jarzenia się łuku i zwarciowego przenoszenia metalu $z$ drutu do jeziorka spawalniczego. Aby ograniczyć niekorzystne narastanie prą$\mathrm{du}$, w latach 80. zastosowano mechaniczne odrywanie kropli na skutek wibracji uchwytem - „wibrostyk” stosowany do regeneracyjnego napawania wałów autobusów, a współcześnie odciąganie drutu szybkim mikrosilniczkiem (funkcja CMT Fronius, rys. 1b) [2]. Niemiecka firma NWM opracowała tranzystorowe źródło pozwalające obniżyć prąd po rozwarciu do wartości przed zwarciem (funkcja cold arc, rys. 1c).

Funkcje CMT i cold arc obniżają moc zajarzania się łuku oraz obniżają temperaturę jeziorka do temperatury topnienia metalu, co pozwala na łączenie blach aluminiowych z ocynkowanymi blachami karoseryjnymi. Niska temperatura jeziorka pozwala łączyć bez przepaleń blachy o szczelinie większej od ich grubości.

\section{Sterowanie prądem}

Innym zagadnieniem wymagającym zimnego jeziorka jest poprawa jakości wykonania przetopów MAG przy zmieniającej się szczelinie w porównaniu z jakością połączeń uzyskiwanych metodą TIG.

Amerykańska firma Lincoln Electric opracowała rozwiązanie STT (rys. 1e) polegające na wcześniejszym wyłączaniu łuku elektrycznego i dosuwaniu, 
bez jarzącego się łuku, kropli przyklejonej do końca drutu. Po zwarciu jest kształtowany impuls narastającego prądu, który formuje wąski mostek ciekłego metalu pomiędzy drutem a jeziorkiem (większa oporność i topienie drutu w zwarciu), który po gwałtownym wyłączeniu prądu zostaje rozerwany. Po czasie potrzebnym do ustalenia równowagi termodynamicznej zostaje schodkowo włączony stabilny łuk elektryczny. Nowsze generacje tego oprogramowania, reklamowane w Australii jako spawarka, która myśli za spawacza, pozwalają na wykrywanie położenia łuku w stosunku do jeziorka i ustawianie większej częstotliwości (mocy), gdy spawacz prowadzi drut na brzegu jeziorka i obniżenie tej częstotliwości w trakcie przesuwania łuku na początek jeziorka, aż do wyłączenia prądu, gdy drut trafia do szczeliny. Spawarka pozwala na wykonywanie przetopów z góry na dół, co w tradycyjnych urządzeniach prowadziło do przyklejeń w przetopie.

Przetop spawarką STT wymaga wykonywania płaskich zygzaków i regulacji przez szerokość zakosów. Takie rozwiązanie sprzyja początkującym spawaczom, ale jest trudne dla specjalistów przyzwyczajonych do tradycyjnych metod.

Wygaśnięcie patentu na STT zmusiło producentów do przeprowadzenia badań fizyki łuku - w Polsce takie badania wykonali fizycy z Uniwersytetu Jagiellońskiego we współpracy z Uniwersytetem w Orleanie, co doprowadziło do powstania konkurencyjnych rozwiązań [1]. Przykładem jest, pokazana na rysunku 1f, funkcja WiseRoot i jej odmiany, ograniczające prąd zwarcia i prąd zajarzenia łuku. Nie ma ona synergii i wymaga w zależności od przyzwyczajeń spawacza (prowadzenie łuku na początku, w środku lub na końcu jeziorka) ustawienia dynamiki łuku i mocy w zależności od warunków odprowadzenia ciepła.

Postęp w obliczeniach wolnego wylotu elektrody pozwolił firmie Kemppi opracować układ automatycznej regulacji, utrzymujący stałą wartość wolnego wylotu elektrody [5]. Wówczas spawanie przypomina spawanie elektrodą otuloną - odsuwany uchwyt powoduje wydłużenie łuku (nagrzanie jeziorka), a dosuwany skraca łuk (wtopienie i chłodzenie jeziorka).

Omówione rozwiązania oparte są na dynamicznym formowaniu prądu na podstawie zmian napięcia w czasie. Ten system sterowania jest kontynuacją rozwojową spawarek o opadającej charakterystyce - zamiast ustalać wartość prądu formuje prąd, w zależności od przebiegu napięcia w czasie.

\section{Sterowanie napięciem}

Odpowiednikiem charakterystyki sztywnej jest przedstawiona na rysunku 1d funkcja arc force, formująca napięcie na podstawie wartości prądu w czasie [8]. Rozwiązanie to umożliwia obniżenie temperatury jeziorka i powoduje, że np. ściegi ze stali nierdzewnej przybierają barwę złotą. Obniżanie napięcia i skracanie łuku ze wzrostem prądu powoduje również odrywanie się

z drutu dużej ilości małych kropel (spray) - zawężenie i spadek temperatury łuku powodujący zwiększenie głębokości wtopienia pozwalające na wykonywanie połączenia przy większym wolnym wylocie elektrody, np. w przypadku złączy materiału o grubości $40 \mathrm{~mm}$,

Ut

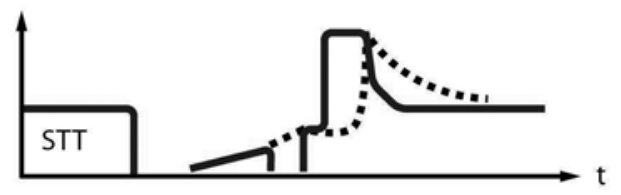

$\mathrm{U}_{\mathrm{t}}$

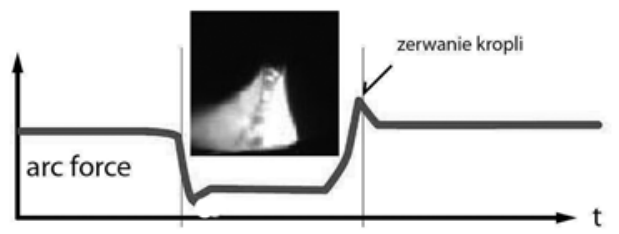

$U_{1}$
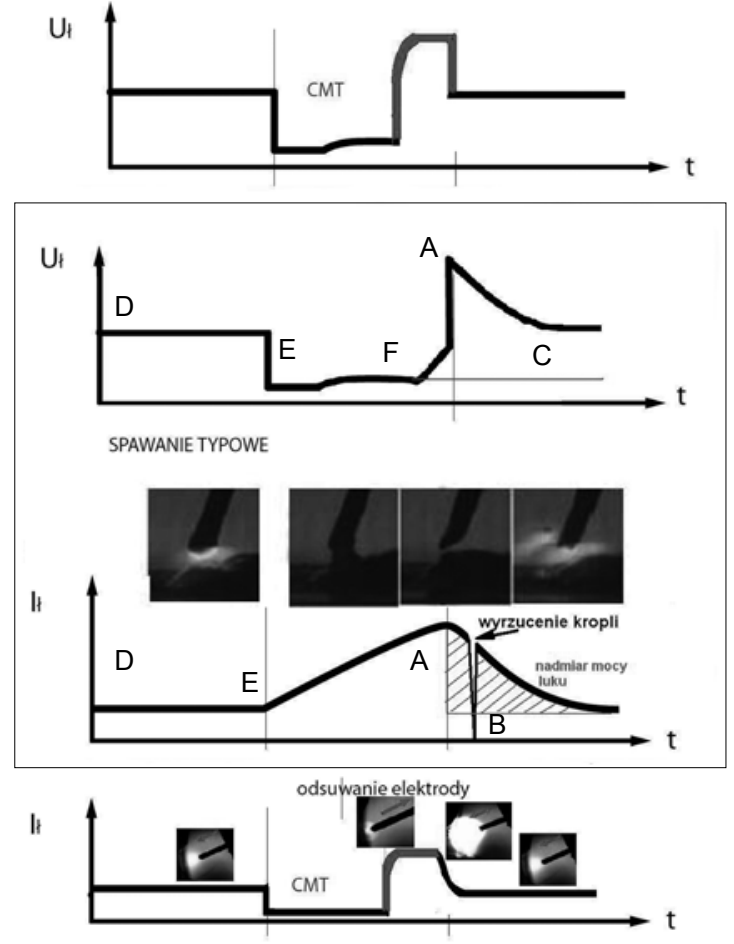

It
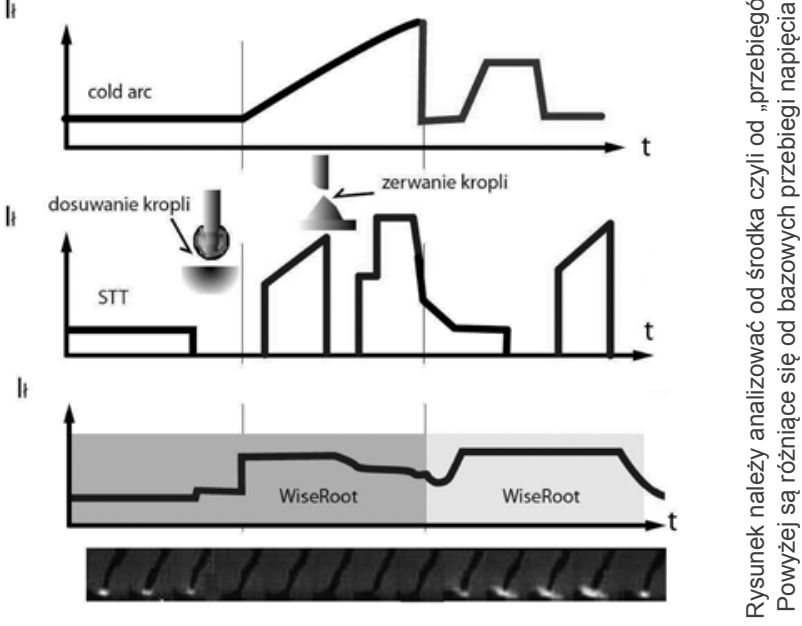

Rys. 1 Porównanie przebiegów prądowych i napięciowych dostępnych na rynku funkcji spawania elektrodą topliwą w osłonie gazów [3] Fig. 1. Comparison of current and voltage waves of gas metal arc welding functions available on the market [3] 
przygotowanego na $1 / 2 \mathrm{~V}$, wykonywanych przy konstrukcji Stadionu Narodowego, gdzie opieranie się dyszy o materiał wymuszało spawanie z dużym wolnym wylotem elektrody.

Połączenie charakterystyki dynamicznej z impulsowaniem prądu (modulowanie przebiegu) lub takie przesuwanie osi (offset), że spawarka pracuje w cyklu prądu zmiennego prostokątnego niesymetrycznego, pozwala przy tych samych wartościach prądu i napięcia regulować szybkością podawania drutu (stapiania), co w tradycyjnych spawarkach było niemożliwe [6]. Pozwala to przy spawaniu pod topnikiem likwidować podtopienia (wzrost temperatury jeziorka) czy zażużlenia (spadek temperatury jeziorka) [1].

Różnica szybkości zmian sterowania i procesów cieplnych powoduje niebezpieczeństwo przesterowania i wpadania układu łuk elektryczny-spawarka w drgania. Nie ma opracowań naukowych na ten temat. W. Lukas i inni przedstawili matematyczną formułę regulatora proporcjonalno-całkująco-różniczkującego i jego parametry stosowane do automatycznej regulacji metodą wizyjną wielkości jeziorka spawalniczego $[7,8]$. Może to być punkt startowy do porównywania parametrów regulatorów spawarek różnych producentów. Należy zwrócić też uwagę na inne układy poprawiające stabilność pracy spawarki, np. układ usuwania kropli i układ cyfrowego filtrowania. Kropla na końcu drutu może zakłócić rozpoczęcie spawania aluminium, natomiast wprowadzenie na wejście regulatora cyfrowego przypadkowych pików może spowodować niepotrzebne przesterowanie i niestabilność procesu. $Z$ tego wynika, że cyfrowe filtrowanie znacznie poprawia jakość spawania elektronicznymi zasilaczami.

\section{Wnioski}

- Obniżenie prądu zajarzenia łuku powoduje, że nawet przy spawaniu w $\mathrm{CO}_{2}$ możliwe jest uzyskiwanie spoiny bez rozprysków.

- Nowoczesne urządzenia falownikowe stosują formowanie prądu przebiegiem napięcia w czasie, co pozwala usprawnić wykonywanie przetopów i lutospawanie blach aluminiowych z ocynkowanymi blachami stalowymi.

- Sterowanie mikroprocesorowe pozwala uzyskać formowanie napięcia przebiegiem prądu, co umożliwia uzyskanie znacznie krótszego łuku natryskowego, dającego złoty ścieg ze stali nierdzewnej i znacznie większą głębokość wtopienia przy spawaniu z długim wolnym wylotem elektrody.

- Rozwiązanie równań równowagi termicznej wolnego wylotu elektrody umożliwia automatyczną regulację jego długością niezależnie od ruchów spawacza, co czyni technikę spawania MAG podobną do techniki spawania elektrodą otulona (ręczna regulacja długości łuku).

\section{Literatura}

[1] Zielińska S., Pellerin S., Dzirzęga K., Valesi F., Musioł K., Briad F.: Measurement of atomic stark parameters of many $\mathrm{Mn}$ and $\mathrm{Fe}$ spectra lines using GMAW process, Journal of Physics D, Vol. 43, 2010. s. 1-10.

[2] Wilhelm G., Shopp G., Uhrlandt D.: Study of the welding gas influence on a controlled shot-arc GMAW process by optical emission spectroscopy, Journal of Physics D, Vol. 43, 2010.

[3] Jastrzębski R.: Mechatronika spawania stopów aluminium i stali, Projektowanie i Konstrukcje Inżynierskie nr 12/2010, s. 39-47.

[4] Oshima K., Xiang S., Yamane S.: Effects of Power Source Charakteristick on $\mathrm{CO}_{2}$ Shot Circuiting Arc Welding, dokument nr IIW Nr XII-1793-2004, Materiały konferencji Międzynarodowego Instytutu Spawalnictwa, Osaka 2004.

[5] Pentegov V., Pismiennyj A.S., Petrienko O.I.: Obliczanie parametrów zmechanizowanego spawania stali w osłonie gazów, Przegląd Spawalnictwa nr 7/2010, s. 33-38.

[6] Jany M.: Nowe technologie w spawaniu, Przegląd Spawalnictwa $\mathrm{nr}$ 7-8/2009, s. 41-45.

[7] Lucas W., Smith J., Balfour C., Bertaso D., Melton G.: Wizyjna kontrola rozmiaru jeziorka spawalniczego $w$ czasie rzeczywistym, Przegląd Spawalnictwa nr 1/2009 s. 11-16.

[8] Jastrzębski A. Tasak E.: Wpływ pulsacji łuku MIG na strukturę spoin stopów aluminium, Przegląd Spawalnictwa nr 7-8/2009, s. 7-11.

\section{Instytut Łączenia Metali w Krakowie}

zaprasza głównych mechaników - i nie tylko - na

\section{KURS FIZYKI I MECHATRONIKI SPAWANIA}

Zamiast jednego superspawacza oferujemy wyszkolenie czterech pracowników:

1. Fizyka i mechatronika spawania - dla głównych mechaników

2. Metalurgia spawania - dla głównych spawalników

3. Projektowanie spoin - dla głównych konstruktorów

4. Kontrola i zapewnienie jakości w spawaniu - dla kierowników kontroli jakości

Kurs jest jednym z serii kursów zgodnych z międzynarodowymi programami łączącymi normy obowiązujące we wschodniej i w zachodniej Europie

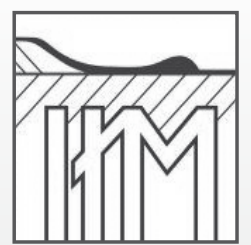

Informacje:

tel.: 126491856 kom.: 608264730 mail: instytut@ilm.pl www.ilm.pl 